doctors anxious to grasp the implications of this development, but it could be helpful to the few already grappling with bio-medical electronics and familiar with computer jargon. It should be of great value to those scientists engaged in the engineering of computers and related equipment. Most of the discussion is orientated around the application of computer techniques to the problem of automatically recording and interpreting electrocardiograms. This is a particularly difficult field but it serves well to illustrate that all those contemplating making use of a computer must formulate their problems in very exact terms.

This book is well produced and has an adequate index. Whether the verbatim presentation is preferable to a conventional report is a matter of opinion but the reviewer found the text stimulating and easy to assimilate. This is a book to be bought by the progressive medical library rather than by the individual pathologist.

$$
\text { F. V. FLYNN }
$$

A SYNOPSIS OF SURGICAL PATHOLOGY By Wilfred Kark. (Pp. 426; 26 figures. 45s.) Bristol: John Wright. 1964.

This pocket-sized book of lecture notes on surgical pathology contains unavoidable simplifications and omissions. Pathologists will regret these, but know how difficult it is to report pathological changes succinctly and completely, and will realize that Mr. Wilfred Kark often succeeds brilliantly with his brief descriptions of the morbid anatomy and histopathology of surgical diseases. The didactic annotated text can be read quickly and a lot of uncontroversial information obtained in a short time.

In this country the teaching of pathology is becoming more closely integrated with that of clinical practice, and few students should find this book essential. Pathologists are more likely to recommend it to their senior technician who helps with the surgical specimens than to medical students, and the fate of this new synopsis will depend upon the amount of goodwill it can generate among students who read this at the eleventh hour before their final examinations.

R. A. B. DRURY

\section{PROTIDES OF THE BIOLOGICAL FLUIDS}

The 13th annual colloquium on the Protides of the Biological Fluids will be held in Bruges on 29-30 April and 1-2 May 1965. Topics to be discussed are lipoproteins, proteins of the nervous system, and impedance measurements of the proteins. At 'round tables' the subjects to be discussed are the physical, chemical, and clinical method of lipoprotein analysis, and the proteins of the nervous system.

All information may be obtained from:-COLLOQUIUM, Protides of the Biological Fluids, जP.B. 71, Bruges, Belgium.

\section{Letter to the Editor}

Sir,

The report on exertional haemoglobinuria in the September 1964 issue of the Journal adds substance to an hypothesis proposed many years ago. In 1903 in the Transactions of the Royal Medical and Chirurgical Society of London (volume 86, page 165), C. W. Ensor and $\mathbf{J}$. $O$. W. Barratt presented a case of 'Paroxysmal haemoglobinuria of traumatic origin'. The patient, a young man with schizophrenia, would lie on his hospital bed violently slapping his forehead for an hour or two, and haemoglobinuria would appear thereafter. The loss of haemoglobin was equivalent to that in 2 or $3 \mathrm{ml}$. of blood. This is, I believe, the only reported case of exertional haemoglobinuria associated with exercise of the upper extremities only. Ensor and Barratt proposed that the haemolysis occurred with the injuring of red cells by the violent slapping, a suggestion which anticipates Dr. Davidson's that exertional haemoglobinuria in runners results from mechanical damage to red cells in the soles of the feet.

$$
\begin{array}{r}
\text { Sincerely yours, } \\
\text { WILliam H. CROSBY, } \\
\text { Colonel, M.C. } \\
\text { Chief, Department of Hematology, } \\
\text { Walter Reed Army Medical Center, } \\
\text { Washington, D.C. }
\end{array}
$$

\section{CORRECTIONS}

Professor I. Friedmann (J. clin. Path., 18, 63-68) writes that his attention has been drawn to another case of rhabdomyosarcoma of the ear in a girl of 4 years which was described by Professor Dorothy Russell in her book written jointly with L. J. Rubenstein ('Pathology of tumours of the nervous system', 1st ed., 1959, page 215). This case has not been described separately in any journal.

In the note on page 134 (J. clin. Path., 18, 1965) it is stated that at the Midland Centre for Neurosurgery determinations of creatine kinase are being regularly carried out by Dr. D. A. Ellis with the support of the Muscular Dystrophy Group. While it is quite true that the Muscular Dystrophy Group have most generously supported Dr. Ellis in research on muscular dystrophy, the determinations of creatine kinase are carried out by Dr. R. A. Westhead in the Centre's biochemistry laboratory without assistance from the Muscular Dystrophy Group.

In the September issue of the paper by A. G. Baikie and E. M. Gillis (J. clin. Path., 17, 573-574) we regret that Figures 2 and 3 have been transposed. 